\title{
Mutant-Firms in the New Economy
}

Judit Kapás

\section{(2) OpenEdition \\ Journals}

Electronic version

URL: http://journals.openedition.org/ei/856

DOI: 10.4000/ei.856

ISSN: 2553-1891

\section{Publisher}

Association Économie et Institutions

\section{Printed version}

Date of publication: 1 December 2004

Number of pages: 77-96

ISSN: 1775-2329

\section{Electronic reference}

Judit Kapás, « Mutant-Firms in the New Economy », Économie et institutions [Online], 5 | 2004, Online since 31 January 2013, connection on 23 April 2019. URL : http://journals.openedition.org/ei/856 ; DOI : $10.4000 /$ ei. 856 


\title{
Mutant-Firms in the New Economy ${ }^{1}$
}

\author{
Judit KAPAS 2
}

\section{Two trends in the New Economy}

Many authors (for instance Mendelson and Pillai 1999, Zenger 2002) find evidence that an increasing number of firms are experimenting with new forms of organizing transactions in the New Economy. More precisely we are witnessing two kinds of transformation process within firms (type I and type II) that take place in parallel.

On the one hand, the firm is becoming more and more infused with high-powered incentives, i.e., firms are moving towards more market-like solutions to organizational problems. This induces, as I will argue in more detail later, changes in the organizational structure of firms, which involves flattening, delayering, using stronger performance pay incentives, empowering employees, ceding authority and so on. As shown in Figure 1, type I transformation leads to the organization of work within the firm in semi-autonomous project-based teams.

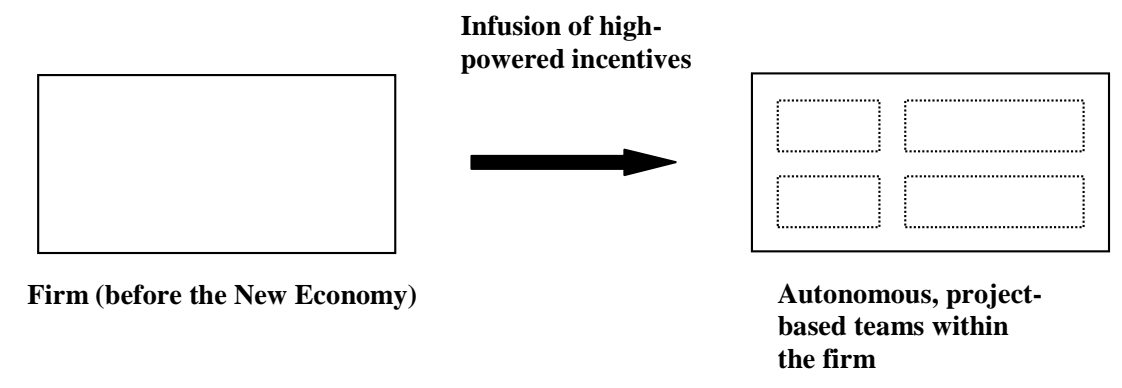

solid lines - legal boundaries of the firm

dotted lines - quasi-boundaries

Figure 1. Type I transformation process Adaptation from Zenger and Hesterley (1997)

On the other hand, firms are changing their scope of activities, typically refocusing on their core businesses and outsourcing many

${ }^{1}$ An earlier version of this paper was presented at the conference "Economie de la firme: quelle nouveautés?", 17-18 April, 2003, Annecy, France. I am grateful to two anonymous referees for their valuable comments and constructive criticism.

2 University of Debrecen, Hungary, judit.kapas@econ.unideb.hu

77 Economie et Institutions $-n^{\circ} 5-2^{e}$ semestre 2004 
of the activities that they previously regarded as central. They are building up long-term relationships in the market and taking advantage of networking. Supplier programs, strategic alliances, networks, subcontracting, joint research and development activities are examples of such relationships. Clearly, these long-term contracts between firms differ to a significant extent from the spot market relationships. In the literature these organizational forms are commonly referred to as hybrids (Williamson 1991, Ménard 2004) and their proliferation as the "swollen middle" (Hennart 1993). Figure 2 shows how autonomous firms are becoming more and more connected to one another via various types of long-term contracts. ${ }^{3}$

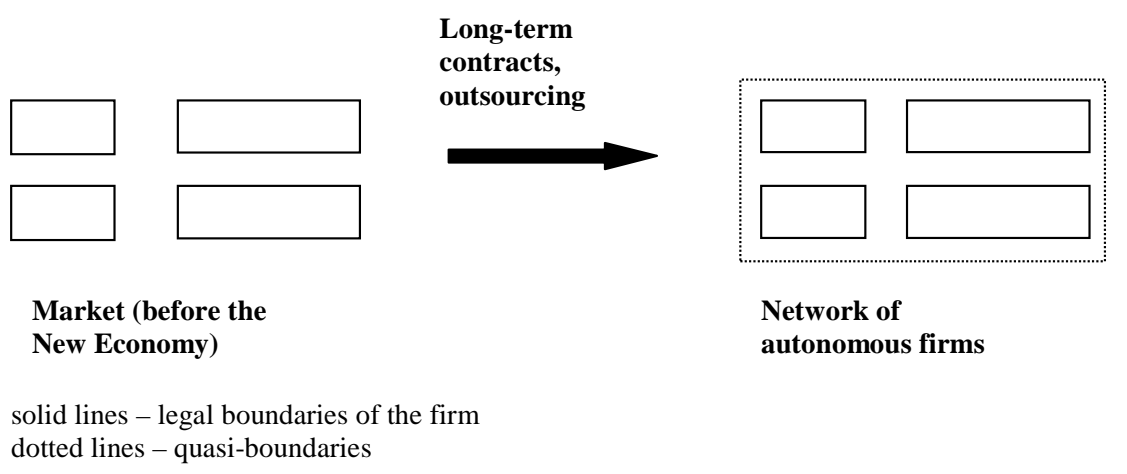

Figure 2: Type II transformation process Adaptation from Zenger and Hesterley (1997)

Although both tendencies concern the firm, they must be clearly distinguished: while the type I transformation occurs within the boundaries of the firm, type II transformation leads to a shift from one organizational form to another, namely from a firm to a hybrid organization.

In this paper I am concerned with the type I transformation. I will analyze the organization of the firm in the New Economy, in comparison with that in the Chandlerian economy, rather than analyzing discrete organizational forms (firms, markets and hybrids $)^{4}$. While the latter issue is addressed in the theory of the

3 Note that the process as shown in Figure 2 looks as if it originated in the market. However, this is not in contradiction with what I am arguing below. For instance, when firms are outsourcing their activities new relationships are established between firms, which is a market phenomenon. But, in fact, these new relationships result from firms' decision on outsourcing, i.e., the whole process is rooted inside the firm.

4 In this paper I distinguish between organizational forms based on the allocation of decision rights, and take the Williamsonian term of governance structure and that of the organizational form as synonymous.

78 Economie et Institutions $-n^{\circ} 5-2^{e}$ semestre 2004 
firm, the former, surprisingly, is rather neglected. However, an explanation for these alternative firm organizations, which I call mutants, must also be incorporated into the theory of the firm. ${ }^{5}$ Contrary to the theory of the firm, organizational theory literature deals with this issue, but there is a conceptual problem with the way this literature treats these types of firm organizations. The point is that the organizational theory literature very often refers to these firm organizations as "new organizational forms"6. I am opposed to this view and will argue that these forms should be regarded as a new mutant of a firm ${ }^{7}$. The important thing is that the "essence" of the firm still remains the same in the New Economy. Accordingly, the end of the "Coasean firm" is simply a myth.

The aim of this paper is to provide an explanation for the nature and emergence of the New Economy's mutant-firm shown in Figure 1. The paper is organized as follows. Section 2 summarizes the main characteristics of the mutant-firm in the New Economy. Section 3, by paralleling the New Economy mutant with the multidivisional firm, addresses the issue of why the New Economy leads to a new mutant form. Section 4 analyzes the distinctive feature of a firm. Section 5 deals with the question of how far the New Economy mutant can go in applying market-like coordinating devices. Section 6 concludes.

\section{A closer look at the new mutant-firm}

Unfortunately, empirical work on organizational structure is relatively limited, Rajan and Wulf (2003) being one of the few exceptions. ${ }^{9}$ In their investigation they used a panel of more than 300 publicly traded US firms over the years 1986-1999. The study focused on two measures of organizational structure: the breadth and depth of the hierarchy. Breadth is represented by the CEO's span of control and is defined as the number of positions reporting to

5 This is in accordance with the proposition of Rathe and Witt (2001) according to which the theory of the firm should also address the developmental (dynamic) versions of the original three Grand Questions. The question of what role change plays in the nature of the firm is one such version.

6 Daft and Lewin (1993) established the term "new organizational form" by simply referring to a new phenomenon, without clearly defining the concept. Drucker (1988) also emphasizes "The Coming of the New Organization".

7 The multidivisional firm is another mutant; that is why I refer to the form in question as a new one. This issue will be discussed at a greater length below.

8 In the "Coasean firm" authority relations constitute its very essence. I will discuss this issue in Section 4.

9 Another significant work is Waytt Data Services (1991).

Economie et Institutions $-n^{\circ} 5-2^{e}$ semestre 2004 
the CEO. Depth represents a vertical dimension of the hierarchy and is defined as the number of positions between the CEO and the divisional CEO. Their first finding is that the number of managers reporting to the CEO has increased steadily over time. The second finding is that the depth, which is the number of positions between the $\mathrm{CEO}$ and the lowest managers with profit center responsibility, has decreased. ${ }^{10}$ As regards the second finding, which is my concern here, a possible interpretation is that the organizational hierarchy is becoming flatter, even while authority is being delegated down the organization. ${ }^{11}$ Besides this exhaustive study, many provide evidence for the decrease in the extent of vertical integration (Carlsson and Taymaz 1994), or downsizing (Pinsonneault and Kraemer 2002).

These empirical facts underpin the view that the process shown in Figure 1 is a significant trend, at least in the American economy. What are the major features of the "outcome" of the type I transformation? Since the mutant-firm is emerging in a process of change, its characteristics, inevitably, can only be stressed in terms of opposition to the structure that prevailed before the change. Here the questions of what the old structure is and what it looks like can be raised. My argument is that the old organizational structure, which, indeed, has dominated since the 1960s, is the Chandlerian multidivisional corporation ${ }^{12}$ (M-form). Let me summarize the defining characteristics of this corporation (Chandler 1977, 1990, Rajan and Zingales 2000). It is (1) large enough to exploit potential economies of scale and scope in production, (2) physical capitalintensive, (3) integrated both forward and backward, (4) oligopolistic, (5) run by professional managers which leads to the agency problem between owners and managers, (6) structured into profit centers

10 The results of Rajan and Wulf's research are rather general in the sense that their sample does not represent particular industries such as telecommunications, information technology, or biotechnology which are, erroneously, very often equated with the New Economy like in Daveri (2002). In this sense, a flattening organization, decentralization of decision-making authority, and the elimination of middle-management layers are common in the whole US economy, and should not by any means, be explained exclusively by the emergence of particular new industries.

11 Note that as a result of a flatter hierarchy both centralization and decentralization could be strengthened. In the sense that the CEO is building direct connections at a deeper level in the organization centralization is stronger. On the other hand, decision-making authority is also being pushed further down, which is a form of decentralization (Rajan and Wulf 2003).

12 The historical development of the multidivisional form is described in Chandler's seminal work (Chandler 1977); this is why it is also referred to as Chandlerian firm. Through the lens of American business history he has given a detailed report on how the multidivisional form evolved through time and became a dominant form in the 1960s.

80 Economie et Institutions $-\mathrm{n}^{\circ} 5-2^{\mathrm{e}}$ semestre 2004 
whose contributions to corporate profit are both directly observable and measurable, and, who are given relatively large autonomy and day-to-day operating decision-making rights.

As opposed to this, the novel organizational structure encompasses a flatter hierarchy - a decentralized decision structure, which is built on self-organizing autonomous teams. These projectbased teams are organized cross-functionally around a well-defined task, observable output or project (Zenger 2002), comprising a mix of individuals with highly specialized competences. Rather than measuring the individuals' performance, the new mutant-firm measures the output of the teams and rewards them. That is, the group functions under market-like control, like an external subcontractor (Helper et al. 2000). The team structure has a profound impact on the sequence of operations: the traditional sequence of research, development, manufacturing, and marketing is being replaced by synchrony since specialists from all these functions work together as a team (Drucker 1988). The role of managers has also changed: they exercise guidance, manage conflict situations and enable communication among the teams rather than directly commanding and controlling them (Child and McGrath 2001). Tasks are fuzzily defined compared to the M-form, and as a consequence the corporate centre can take advantage of the teams' entrepreneurship and responsibility. Due to the fact that employees are specialists, human capital and knowledge are becoming increasingly important relative to inanimate assets. As the importance of human capital grows, power also moves away from the top and is much more widely dispersed through the firm. ${ }^{13}$ The character of specialization has also been changed (Rajan and Zingales 2000): while the employees of the Chandlerian firm are technically specialized to the firm, those of the new mutant have firm-specific capabilities.

More importantly, authority changes in character ${ }^{14}$ : a high degree of discretion is granted to lower levels. As a result, the new mutant form tends to be not only strongly decentralized, but also quite loosely coupled. Briefly, the New Economy's mutant-firm ${ }^{15}$

13 Control over valuable human capital seems to be a greater source of power than control over physical assets since almost all rights over it are residual, i.e., not allocable through contract (Rajan and Zingales 2000).

14 I will emphasize later that, although authority changes, it remains a distinguishing feature of the firm; and that is the reason why the new firm organization must be considered a mutant of a firm, rather than a "new organizational form". This means that authority is the key in my argumentation.

15 Since there is no established terminology as regards this firm organization, due to a diversity of the forms themselves, I prefer not to use any particular term.

Economie et Institutions $-n^{\circ} 5-2^{e}$ semestre 2004 
relies more on high-powered incentives that are often seen as "virtues" of the market. Table 1 explores the main differences between the Chandlerian firm and the New Economy mutant.

\begin{tabular}{|c|c|c|}
\hline Criterion & M-form & New Economy Mutant \\
\hline Structure & $\begin{array}{cl}\text { Vertically integrated } \\
\text { - } & \text { Top-down goal } \\
\text { - } & \text { setting } \\
& \text { Concentrated } \\
\text { - } & \text { power } \\
& \text { Hierarchy (vertical } \\
& \text { relationships) } \\
\text { - } & \text { Leaders control, } \\
& \text { monitor and set } \\
& \text { specific and } \\
& \text { concrete objectives } \\
& \text { through the use of } \\
& \text { formal authority } \\
\text { - } & \text { Clear role } \\
& \text { definitions } \\
\text { - } & \text { Formal rules }\end{array}$ & 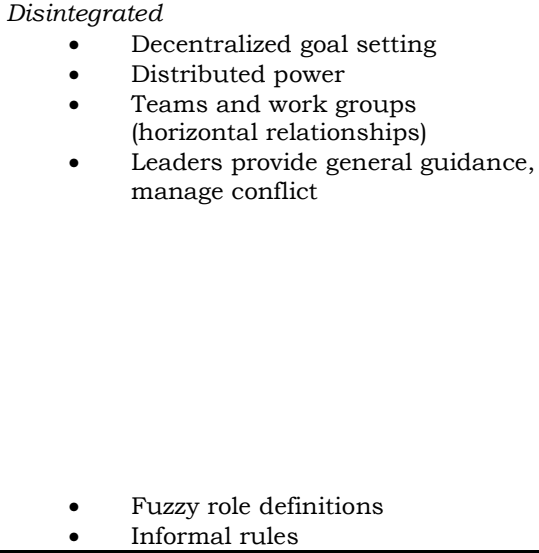 \\
\hline Critical Asset & $\begin{array}{l}\text { Inanimate (physical) } \\
\text { capital }\end{array}$ & • $\quad$ Human capital \\
\hline Specialization & Technical & Firm-specific \\
\hline Source of Power & $\begin{array}{l}\text { Control over physical } \\
\text { assets }\end{array}$ & - $\quad$ Individual's valuable resource \\
\hline Economies & $\begin{array}{ll}\text { Economies of scale and } \\
\text { scope }\end{array}$ & $\begin{array}{ll}- & \text { Economies of scope } \\
- & \text { Modularity } \\
\end{array}$ \\
\hline Demand & $\begin{array}{l}\text { Undifferentiated } \\
\text { products }\end{array}$ & - $\quad$ Distinctive and individualized \\
\hline Firm Boundary & $\begin{array}{l}\text { Boundaries clearly } \\
\text { specified and durable }\end{array}$ & $\begin{array}{ll}- & \text { Boundaries permeable and fuzzy } \\
\text { Quasi-contractual inter-teams } \\
\text { relationships }\end{array}$ \\
\hline Reward & $\begin{array}{l}\text { Based on individual } \\
\text { performance }\end{array}$ & - $\quad$ Based on team performance \\
\hline $\begin{array}{l}\text { Transaction } \\
\text { Costs within the } \\
\text { Firm } \\
\text { (coordination, } \\
\text { agency, shirking, } \\
\text { contract } \\
\text { enforcement } \\
\text { costs) }\end{array}$ & Low & - $\quad$ High \\
\hline
\end{tabular}

Table 1. Comparison of the Chandlerian firm with the New Economy's mutant-firm

\section{The New Economy and the new mutant}

My argument is that the above-described form must be considered a new mutant of a firm, which we should understand in line with the M-form put forward by Chandler (1977). This flows from the fact that the firm is subject to a slow evolution process which

82 Economie et Institutions $-\mathrm{n}^{\circ} 5-2^{\mathrm{e}}$ semestre 2004 
produces new mutants at various times. In what follows I will explore how and why the New Economy leads to the emergence of a new mutant, which, indeed, requires an understanding of the New Economy itself.

Most authors agree that the term New Economy captures the important shift in the US economy that took place in the 1990s, although opinions differ about the nature of this shift. ${ }^{16}$ According to Foss (2002) the major effect consists in the fact that knowledge has become increasingly dispersed in the sense of Hayek (1945). D'Aveni (1994) puts the emphasis on the acceleration of the speed of innovation and of technological development, which changes the character of competition. ${ }^{17}$ Another important change is to be found in the differentiation of consumers' preferences, which leads to customization (Da Silveira et al. 2001).

Thus, all these authors shed light only on a particular aspect of the New Economy. Togati (2003) proposes a broader definition. The point is that the New Economy is a complex phenomenon, comprising a number of phenomena such as the above-mentioned features, or additionally IT, globalization, the increasing weight of finance, more intense competition and so on. It is clear that all these features must be taken into account, rather than focusing on one factor taken in isolation. On the other hand, as Togati (2003) argues, the New Economy concerns a historical process capturing permanent and structural effects. In this light, it may be paralleled with the process Chandler (1977) has described. The crucial point is that the New Economy is a continuity of the Chandlerian process and does not represent the third industrial revolution. The thing is that technological progress interacts with a number of other factors, such as fundamental institutions, which may be relatively stable through time. A true revolution occurs only when technology is able to affect these factors as well (Togati 2003). The New Economy is not a revolution since it occurs within a broad institutional framework which was constructed between the end of the $19^{\text {th }}$ century and the beginning of the $20^{\text {th }}$ century. ${ }^{18}$ What is the significant difference between the New Economy and the Chandlerian economy? The novelty of the New Economy lies in the combination of its individual

16 Numerous scholars (e.g., Brynjolfsson et al. 1994) argue that the process of change characterizing the New Economy occurs most markedly in the US economy, but, even in the US it is somehow geographically concentrated; and Europe is reckoned to lag behind the US (Daveri 2002).

17 This new type of competition is referred to as a hypercompetition. The point is that on the one hand, the competitive advantages persist for shorter periods, and on the other hand disturbances are frequent (D'Aveni 1994).

18 Alternatively, the New Economy is also referred to as the entrepreneurial economy, and the Chandlerian economy as the managed economy (Audretsch and Thurik 2000).

Economie et Institutions $-\mathrm{n}^{\circ} 5-2^{\mathrm{e}}$ semestre 2004 
ingredients and the acceleration of technological change (Togati 2003). In other words, the New Economy accelerates some tendencies that started at the mid of the $20^{\text {th }}$ century; accordingly, the tendency itself is not a new one.

The consequences are the transformation processes shown in Figure 1 and 2. On the one hand, there is a shift to the market (Figure 2) which is characterized by Langlois (2003) as a vanishing hand in which the coordination by management (visible hand) is replaced by market coordination (invisible hand). This process "from Adam Smith to present has been characterized by a continual substitution of large organizations for the markets" (Simon 2002, p. 414). However, in the New Economy there is also a well documented trend (for instance in Roberts 2004) to the proliferation of projectbased firms as shown in Figure 1.

An advantage of taking the above perspective on the New and Chandlerian Economies consists in the fact that it constitutes a coherent framework for an understanding of the mutants of the firm. In this perspective both the Chandlerian multidivisional form and the New Economy firm must be perceived as mutants as opposed to the tightly coupled, highly centralized hierarchy. My argument, in accordance with Powell (2001), is that there have been two major evolutions in the structure of organizations. The first begun at the turn of the $19^{\text {th }}$ and $20^{\text {th }}$ centuries, and led to the birth of the multidivisional firm. Some 10 years ago we entered a second period of organizational change. Following this line of reasoning I argue that two kinds of mutants of the capitalist firm can be distinguished: the M-form and the New Economy firm. ${ }^{19}$

\footnotetext{
19 Note that the firm form I call the New Economy mutant was referred to by Mintzberg (1979) as adhocracy. By that he meant such an organizational configuration that is complex and non-standardized, and has a project-based structure in which the managers do not control in the sense of direct supervision. Interestingly, as early as 1979, Mintzberg had already identified almost all the features I explored in Section 2. However, he noted that all other organizational configurations he distinguished are either passé or simply current, but that the adhocracy "is clearly tomorrow's" structure (Mintzberg 1983, p. 275). Apparently Mintzberg's 'tomorrow' is our 'today'. What is of importance is that the Mintzbergian organizational configuration theory and his five categories are not in contradiction with my concept of mutants of the firm. The point is that I have a broader, rather more historical perspective as regards the evolution of a firm, while Mintzberg is interested in analyzing organizations according to some concrete criterion (elements of the configurations) such as job specialization, behavior formalization, and so on (Minzberg 1981, Appendix). I think that Mintzberg's configurations and my concept of mutants are useful simply for different theoretical purposes.
}

84 Economie et Institutions $-n^{\circ} 5-2^{e}$ semestre 2004 
In what sense should the new mutant be seen as an efficient response to the changes in the New Economy?20 Firstly, it is an efficient organizational solution to the decomposition of complex problems into simpler sub-problems. As highlighted by Foss and Foss (2002) firms confront new problems, or at least, the architecture of the existing problems has changed in the New Economy. These can be referred to as ill-structured problems in a Simonian sense (Simon 1973). Simon argues that any ill-structured problem can be made structured (solvable) through certain process of transformation: the key point in the resolution of these problems consists in the decomposition of the problems into sub-problems (Simon 1962). The New Economy mutant may be adopted to solve this problem by imposing structure on ill-structured problems. It seems that firms resolve this problem by the decomposition of the organization into elements, i.e., project-based teams. That is, the decomposition of the complex problem may be obtained through the decomposition of the organization. In this sense the new mutant represents an efficient solution to the complex problems that arise in the New Economy.

On the other hand, with relation to hypercompetition, uncertainty has increased in the New Economy. As Langlois (2003) argues, environmental uncertainty requires some form of buffering. There exist two types of buffers, namely human cognitive capabilities (management) and the price system (market). The types of buffers to be used depend on space and time. In a highly uncertain environment such as the New Economy modular systems have comparative advantage over non-modular ones. Being more modular, the new mutant-firm is more suitable to the requirements of the New Economy.

To summarize, the New Economy mutant has brought about changes within the firm in order to solve complex problems and buffer uncertainty in an efficient way.

\section{The distinctive mark of a firm}

20 In this paper I build upon the concept of the contingent fit as proposed in contingency and configuration theories, organizational ecology, and transaction costs economics. The reason is that, following Langlois (2003), it is technological changes that are the driving force behind the evolution of firm organization - although of course there have been a number of contributing factors and an interplay between them. It is worth noting that, according to Nickerson and Zenger (2002), organizational changes often seem difficult to explain as merely responses to exogenous environmental changes. They suggest that under certain conditions, even in the absence of environmental change, managers may stimulate change in organizational structure.

Economie et Institutions $-n^{\circ} 5-2^{e}$ semestre 2004 
Both the M-form and the New Economy firm are mutants as opposed to Zenger's view (Zenger 2002) which regards the latter as a discrete governance structure. Zenger, by focusing exclusively on a unique bundle of complementary features of the new mutant-firm, neglects its most important characteristic. The important thing is that both the M-form and the new mutant-firm are essentially of the same nature, i.e., they are firm organizations. To put it differently, mutants exhibit to a certain extent different characteristics while retaining the same distinctive feature. This being said, we have to investigate the question of what is common in all mutants of the firm. So, what is this distinctive mark of a firm? An understanding of the essence of a firm requires us to establish the unique attribute of a firm, i.e., that which exclusively characterizes it as opposed to the market and hybrid form.

In my view, a distinction between coordination mechanisms (devices) and arenas of coordination may be useful in this understanding. I have argued elsewhere (Kapás 2002) that the firm, like the market, should be considered an arena rather than a mechanism of coordination. The firm is a complex of coordinating devices (Ménard 1994), i.e., it encompasses diverse coordinating mechanisms. Mutants of the firm differ from one another in the mix of various coordinating mechanisms ${ }^{21}$ they comprise. For instance the M-form uses more market-like coordinating mechanisms (highpowered incentives) as opposed to the highly centralized hierarchy, and the same applies for the new mutant as compared with the Mform. The tendency is clear: moving from the tightly coupled, centralized hierarchy towards the M-form, and then towards the New Economy mutant, the mix of the coordinating mechanisms shifts towards encompassing more and more high-powered incentives. ${ }^{22}$

Let me turn back to the question of what makes a firm a firm. Coase (1937) was the first to discuss this issue. He argued that "the distinguishing mark of the firm is the supersession of the price mechanism" (Coase 1937, p. 389). By this he referred to the authority relation as creating the essence of the firm. ${ }^{23}$ Without

21 Coordinating mechanisms are authority, command, price system, trust, reciprocity, etc.

22 This means that there is a relatively large area within which high-powered incentives may be applied within a firm. The question of what limits the use of market-like coordinating devices will be addressed in Section 5 .

23 Note that many argue (among others Langlois and Foss 1999) that Coase was wrong to consider the suppression of the price system as the distinguishing feature of the firm by arguing that the two things Coase referred to are not the same. The counter-argument is that firms use transfer (shadow) prices, which aim to imitate market prices within the firm. Note also that transfer prices are not (true) market prices and their use serves,

86 Economie et Institutions $-\mathrm{n}^{\circ} 5-2^{\mathrm{e}}$ semestre 2004 
giving a clear-cut definition, he understood authority as the relationship between the employee and employer (entrepreneur): the entrepreneur exercises direction, and employees agree to obey to him/her within certain limits (ibid. p. 391). This concept of authority was formalized by Simon (1951) and has become common in the literature: authority refers to the manager's right to direct the workers within their "zone of acceptance". Here authority is based upon the control and monitoring of individual efforts.

The organizational context is, in several respects, different in the New Economy mutants, where employees are given a great amount of autonomy and a number of decision-making rights are delegated. In this case, as a number of scholars (Foss 2002, Brusoni 2003) argue, the Coasean-Simonian view of authority is too narrow. This is "because it implies that the boss directs the worker's actions in detail, based on a complete knowledge of the worker's action set, and because it implicitly asserts that the boss is always at least as, or more, knowledgeable about what actions should optimally be carried out" (Foss 2002, p. 19). Consequently, the concept of authority has to be extended. A broader concept of authority should take into account the fact that decision rights are delegated in firms. Authority in a broader sense is about deciding what decisions can be delegated to employees or project partners when decomposing complex problems into simpler sub-problems, and about deciding where to set the limits to the discretion allowed to agents to whom decisions are delegated (Foss and Foss 2002). By delegating the solution of each sub-problem to specialists in teams, the foundations of authority are to be found not only in the ownership of tangible assets.

This being said, the question of whether authority (in a broader sense) is a distinguishing mark of a firm arises. The answer is not obviously 'yes' since markets and, especially, hybrids are also infused with a lower level of authority. ${ }^{24}$ To provide an answer, understanding authority as a coordination device, as proposed above, is of paramount importance. My argument is that, despite the penetration of market-like coordinating devices, authority remains the primordial coordinating mechanism within the firm.

Case studies in the organizational theory literature provide support for this argument. Let me cite an example, namely the

partly, other purposes than ensuring efficient resource allocation. Nevertheless, they are much more similar to market prices than to commands used exclusively by firms.

24 Many scholars argue and provide evidence for the fact that a kind of authority is observable in hybrids (Ménard 2004) and in market contracts (Stinchcombe 1985).

Economie et Institutions $-n^{\circ} 5-2^{e}$ semestre 2004 
Oticon case that is discussed in Foss (2003). ${ }^{25}$ The Danish firm Oticon, founded in 1904, is one of the world market leaders in hearing aids. The company became world famous for radical organizational transformation in the early 1990s. The background was the loss of competitive advantage during the 1980s. The new organizational structure, namely the "spaghetti organization", was a loosely coupled, almost $100 \%$ project-based organization characterized by ambiguous job boundaries and extensive delegation of responsibilities to autonomous teams. The significant thing is that the firm was entirely organized on the initiatives of firm members: anybody had the right to initiate a project, and employees could decide which projects they would join. Project managers were free to manage the project in all respects: they were given a great amount of decision-making power and the right to negotiate salaries. Nevertheless, all development projects initiated by individuals had to receive approval from the Project and Product Committee.

The implementation of the new structure had marked and rapid effects on performance. However, the major problem was that the Project and Product Committee, because it had the ultimate decision-making power could veto any project initiated by the teams. That is, in spite of delegating many decision-making rights, the CEO possessed very considerable decision-making powers, and could intervene in projects, for instance by closing down them. Finally, these interventions led to severe performance problems, and consequently, the restructuring of the firm towards a more hierarchical form.

A lesson from this case is that since the Project and Product Committee could overrule the employees, authority has supremacy over the other coordinating devises used within the firm and it can never vanish inside the firm unlike in the market. That is the distinctive mark of a firm. This also implies, as Foss (2001) argues, that centralized coordination (authority) is always needed within firms. ${ }^{26}$

It is worth noting that the ideas developed in the system theory, although originating from another perspective, seem to largely support the above argument on the "essence" of the firm. A firm as a complex system requires rules (Foster 2005) which change through time. As a result of this process there are rules that are common to all firms and those that are unique to particular firms. The common rules constituting the distinctive mark of the firm concern the connective structure, i.e., hierarchy (authority) of the

25 Other cases can be found, among others, in Lindkvist (2004) and Kakihara (2004).

26 According to Foss (2001), the reasons why authority is always needed are as follows: (1) the need for urgent coordination, (2) decisive information, (3) economies of scale in decision-making, (4) economies of scale in monitoring.

88 Economie et Institutions $-\mathrm{n}^{\circ} 5-2^{\mathrm{e}}$ semestre 2004 
firm; these rules serve to connect together the elements of the system. In addition, Mesarovic et al. (1970) put the emphasis on the multilevel character of the firm's hierarchical system. They build upon the view that the decision-making units in the multilevel systems possess discretion; the extent of this discretion being precisely where the M-form and the new mutant differ. Moreover, the concept of authority in a broader sense is built upon the concept of discretion, as argued above.

Quite naturally, this approach is connected to March and Simon's (1958) treatise on conflict-resolution ${ }^{27}$ within the firm which directs our attention to an additional lesson taken from the Oticon case: after a certain period and even despite the first success, the "spaghetti organization" was partially abandoned and it was gradually superseded by the previous, apparently more stable organizational structure. Obviously, this has to do with what was proposed in Cyert and March (1963). The quasi-resolution of conflict - according to which firms function with considerable conflicts of interests between groups, but do not necessarily resolve these conflicts - is becoming an even more severe problem in the projectbased organizational form. Since this firm form tends to give a birth to a larger number of conflicts between teams, in order to achieve a consistency between teams' goals, top management (the Project and Product Committee) must retain the ultimate decision-making right for itself. This points to the fact that the extent to which highpowered incentives can be used within the firm is constrained.

\section{How radical can the New Economy mutant be?}

The above view needs to be analyzed in more detail. The major question is what limits the use of high-powered incentives within a firm. Not surprisingly, several factors intertwine.

As mentioned above, the New Economy favors those systems that are capable of decomposing complex problems into simpler subproblems, and the new mutant-firm is such a system. Moreover, the process of decomposition cannot reach a situation whereby all subproblems include all and only the elements that are independent of each other (perfect decomposability), i.e., complex problems are only nearly decomposable 28 (Simon 1996). As Simon argues neardecomposability is a permanent feature of organizational architecture, consequently, over non-decomposable problems top

27 Mesarovic et al. (1970) have developed a formalized theory of conflictresolution and coordination in multilevel hierarchical firms.

28 In a nearly-decomposable system the interactions among sub-systems are weak, but not negligible (Simon 1962, p. 129).

Economie et Institutions $-n^{\circ} 5-2^{e}$ semestre 2004 
management (authority) reserves ultimate decision-making rights for itself.

Another limit is what Williamson (1996, p. 150) identified as the impossibility of selective intervention. Selective intervention refers to the promises of the managers to intervene in the affairs delegated to the employees only with good cause, i.e. when the processes take an undesirable turn. Williamson argues that selective intervention is impossible; that is, the promise of the manager to overrule the employee's decision only in difficult situations is not credible because these promises are unenforceable. This means, as is also seen in the Oticon case, that the person who has the ultimate decision rights can always control and overrule employees.

In addition, there are costs associated with using fewer administrative devices (authority), such as agency costs. These costs also constrain the extent to which market-like coordinating devices can be used within the firm. Decision rights should be delegated in such a way that the advantages from delegation - which result in a better use of local knowledge - counterbalance the costs of delegation, i.e., losses from agency (Jensen and Meckling 1992). Assuming that the agency costs increase monotonically and the costs owing to poor knowledge decrease monotonically as more decision rights are allocated to subordinates, the optimal decentralization of decision rights (authority) can not occur at a point at which decision rights are completely decentralized. This argument is illustrated in Figure 3.

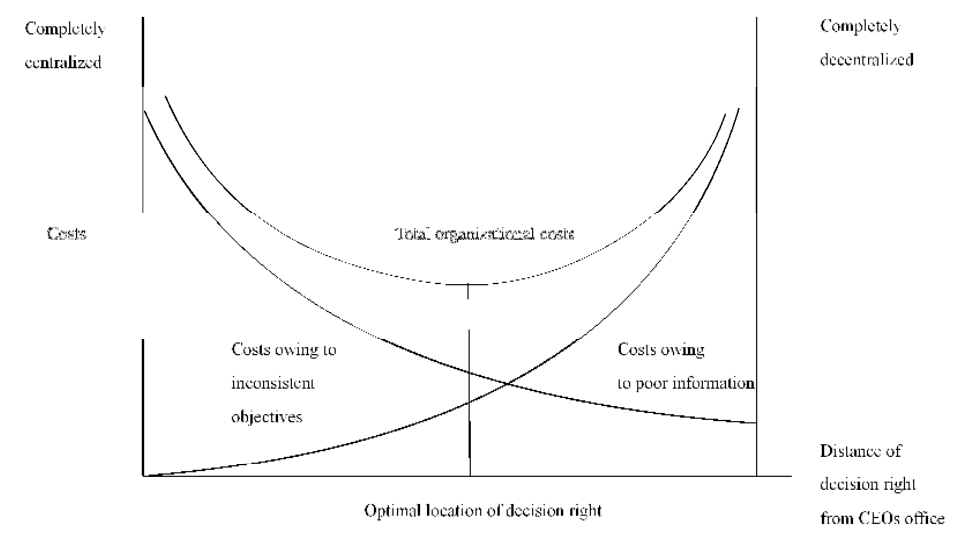

Figure 3. The optimal decentralization of decision rights

Source: Jensen and Meckling (1992, p. 263)

90 Economie et Institutions $-\mathrm{n}^{\circ} 5-2^{\mathrm{e}}$ semestre 2004 
Modularity also limits the extent to which high-powered mechanisms can be applied. At a more abstract level modularity refers to the degree to which a system's components can be separated and recombined without a significant loss of functionality (Shilling 2000, p. 315).29 Since all systems exhibit some degree of modularity, the question to be raised is not whether a system is modular, but to what degree it is modular.

More recently modularity theory has been applied to social organizations as well. As Langlois (2002) argues, a market is an extremely modular organizational form, while "firms arise as islands of non-modularity in a sea of modularity" (Langlois 2002, p. 34). Nevertheless, when the firm uses more high-powered incentives like the New Economy mutant-firm, it becomes infused with more modularity. That is, from a modularity point of view the difference between the firm and the market is a matter of degree, rather than being a matter of kind. But, modularity is constrained inside the firm because of the synergistic specificity of the firm's components, which means that the firm as a whole can perform better compared to when it is (to too large an extent) decomposed (Schilling 2000). So, the firm cannot become as modular as the market.

\section{Conclusions}

Based on the above, one conclusion is that the firm cannot use the coordinating devices in any arbitrary mix. ${ }^{30}$ Although the scope for applying high-powered incentives is relatively large, authority remains primary. This is the distinctive mark of a firm. When compared to a previous state - firm organization is infused with a large number of market-like incentives that profoundly affect the whole firm organization, a mutant emerges. This can be dramatically illustrated in the examples of both the M-form and the New Economy mutant.

The New Economy mutant has just superseded the M-form by applying more high-powered incentives within the boundaries of the firm. Several facts suggest that the M-form uses market-like coordinating devices to the detriment of command and administrative devices: division managers are given legitimacy and

29 The components of a modular system are relatively independent of one another and are easily combinable with the others (Baldwin and Clark 2000). 30 As seen in the Oticon case, when applying a market-like coordinating mechanism to too large an extent within the firm, there arises an efficiency loss and the firm reverts to a more hierarchical structure. Note also that, in opposition to this view, Grandori (1997) argues that coordinating mechanisms can be combined arbitrarily along a continuum.

Economie et Institutions $-n^{\circ} 5-2^{e}$ semestre 2004 
power, their rewards are based on division profits, there is competition for financial resources between divisions, and so on. Accordingly, compared to the highly centralized hierarchy, the Mform's divisions are encouraged to behave in a more entrepreneurial way, not as departments in the centralized hierarchy, but rather like the project-based teams in the New Economy mutant-firm. That is, the tendency is clear: the technological-institutional process of change from the middle of the $19^{\text {th }}$ century induces a shift from the highly centralized hierarchy towards the M-form, and then towards the New Economy mutant by changing the mix of the coordinating mechanisms towards encompassing more and more high-powered incentives. Accordingly, mutants of the firm (M-form and the New Economy firm) should be conceived as comprising a varied mix of low and high-powered incentives.

Taking into account the character of the whole process, the novelty of the New Economy mutant as well as the New Economy itself should not be overestimated: the New Economy should not be mystified as it is in the media. The New Economy has been described by the media as 'the Internet age', 'the IT revolution', and 'the digital era'. These terms seem to have an exaggerated connotation. As suggested above, IT, the Internet and telecommunication technologies can be paralleled with the technological innovations including the telegraph, the development of continuous process machinery, the refinement of interchangeable parts manufacture, and the railroad (Chandler 1977) - that took place from the mid 19th century, giving birth to the M-form. Similarly, the Internet and IT led to the new mutant-firm. Both the M-form and the new mutant-firm have been appropriate responses to the requirements of their own age and have comparative advantage in particular economic systems.

As a consequence, those segments of an economy that are loosely interwoven with the New Economy may not favor the new mutant, and, as a result a number of firms may retain a more hierarchical structure. Recall that it took almost half a century for the $\mathrm{M}$-form to become a dominant form. Apparently, we are just at the beginning of the New Economy, and we do not know how much time it will take for the new mutant to spread in the economy, if indeed this form will prove at all viable. It is unclear now whether the entire economy is disaggregating as proposed by Zenger and Hesterley (1997), or whether the current period will, finally, settle down. Surely, the coexistence of mutants will prevail for a while.

\section{References}

Audretsch, D. B. and A. R. Thurik, (2000), "What's New about the New Economy? Sources of Growth in the Managed and 
Entrepreneurial Economy", Industrial and Corporate Change, 10 (1), pp. 267-315.

Baldwin, C. Y. and K. B. Clark, (1997), "Managing in an Age of Modularity", Harvard Business Review, 75 (5), pp. 84-93.

Brusoni, S. (2003), Authority in the Age of Modularity, SPRU Working Paper No. 101. University of Sussex, UK.

Brynjolfsson, E. - T. W. Malone - V. Gurbaxani and A. Kambil, (1994), "Does Information Technology Lead to Smaller Firms?", Management Science, 40 (12), pp. 1628-1645.

Carlsson, B. and E. Taymaz, (1994), "Flexible Technology and Industrial Structure in the U.S.", Small Business Economics, 6 (3), pp. 193-209.

Chandler, A. D. (1977), The Visible Hand: the Managerial Revolution in American Business, Cambridge, MA., Harvard University Press.

Chandler, A. D. (1990), Scale and Scope: The Dynamics of Industrial Capitalism, Cambridge, MA., MIT Press.

Child, J. and R. McGrath, (2001), "Organizations Unfettered: Organizational Forms in an Information Intensive Economy", Academy of Management Journal, 44, pp. 1135-1148.

Coase, R. H. (1937), "The Nature of the Firm", Economica, 4 (16), pp. 386-405.

Cyert, R. M. and J. G. March, (1963), A Behavioral Theory of the Firm, $2^{\text {nd }}$ edition, Cambridge, Blackwell Publishers. 1992.

D'Aveni, R. (1994), Hypercompetition: The Dynamics of Strategic Maneuvering, New York, Basic Books.

Da Silveira, G. - D. Borenstein and F. S. Fogliatto, (2001), "Mass Customization: Literature Review and Research Directions", International Journal of Production Economics, 72 (1), pp. 1-13.

Daft, R. and A. Lewin, (1993), "Where Are the Theories of the "New" Organizational Forms?", Organization Science, 4, pp. i-iv.

Daveri, F. (2002), The New Economy in Europe 1992-2000, Discussion Paper No. 2002/70, World Institute for Development Economics Research, Helsinki, Finland.

Drucker, P. F. (1988), "The Coming of the New Organization", Harvard Business Review, January-February, pp. 45-53.

Foss, K. and N. J. Foss, (2002), Simon on Problem-Solving: Implications for New Organizational Forms, LINK Working Paper, Copenhagen.

Foss, N. J. (2001), "Misesian Ownership and Coasian Authority in Hayekian Settings: The Case of the Knowledge Economy", Quarterly Journal of Austrian Economics, 4 (4), pp. 3-24.

Foss, N. J. (2002), "Coase vs Hayek': Authority and Firm Boundaries in the Knowledge Economy", International Journal of the Economics of Business, 9 (1), pp. 9-36.

Foss, N. J. (2003), "Selective Intervention and Internal Hybrids: Interpreting and Learning from the Rise and Decline of the Oticon 
Spaghetti Organization", Organization Science, 14 (3), pp. 331349.

Foster, J. (2005), The Simple Analytics of the Firms as a Complex System, Paper for the EMAEE Conference, 2005, Utrecht.

Grandori, A. (1997), "Governance Structures, Coordination Mechanisms and Cognitive Models", Journal of Management and Governance, 1, pp. 29-42.

Hayek, F. A. (1945), „The Use of Knowledge in Society”, American Economic Review, 35 (4) pp. 519-530.

Helper, S. - J. P. MacDuffie and C. Sabel, (2000), "Pragmatic Collaborations: Advancing Knowledge While Controlling Opportunism", Industrial and Corporate Change, 9 (3), pp. 443487.

Hennart, J. (1993), "Explaining the Swollen Middle: Why Most Transactions Are a Mix of 'Market' and 'Hierarchy", Organization Science, 4, pp. 529-544.

Jensen, M. C. and W. H. Meckling, (1992), „Specific and General Knowledge, and Organizational Structure", in Werin, L. and H. Wijkander (eds.), Contract in Economics, Cambridge, MA., Basil Blackwell, pp. 251-274.

Kakihara, M. (2004), "The Rise of the Fluid Organization?: Organizational Patterns of Mobile Professional Work", in Proceedings of the 27th Information Systems Research Seminar in Scandinavia (IRIS-27), Falkenberg, Sweden.

Kapás, J. (2002), "Piacszerủ vállalat és vállalatszerű piac" (Marketlike Firm and Firm-like Market). Közgazdasági Szemle (Economic Review), XLIX (4), pp. 320-333.

Langlois, R. N. (2002), "Modularity in Technology and Organization", Journal of Economic Behavior and Organization, 49, pp. 19-37.

Langlois, R. N. (2003), "The Vanishing Hand: the Changing Dynamics of Industrial Capitalism", Industrial and Corporate Change, 12 (2), pp. 351-385.

Langlois, R. N. and N. J. Foss, (1999), "Capabilities and Governance: the Rebirth of Production in the Theory of Economic Organization", Kyklos, 52 (2), pp. 201-218.

Lindkvist, L. (2004), "Governing Project-based Firms: Promoting Market-like Processes within Hierarchies", Journal of Management and Governance, 8, pp. 3-25.

March, J. G. and H. A. Simon, (1958), Organizations, New York, Wiley.

Ménard, C. (1994), "Organizations as Coordinating Devices", Metroeconomica, 45 (3), pp. 224-247.

Ménard, C. (2004), "The Economics of Hybrid Organizations", Journal of Institutional and Theoretical Economics, 160, pp. 1-32.

94 Economie et Institutions $-\mathrm{n}^{\circ} 5-2^{\mathrm{e}}$ semestre 2004 
Mendelson, H. and R. R. Pillai (1999), "Information Age Organizations, Dynamics, and Performance", Journal of Economic Behavior and Organization, 38, pp. 253-281.

Mesarovic, M. D. - D. Macko and Y. Takahara, (1970), Theory of Hierarchical, Multilevel, Systems, New York, London, Academic Press.

Mintzberg, H. (1979), The Structuring of Organizations, Englewood Cliffs, N. J., Prentice Hall.

Mintzberg, H. (1981), "Organization Design. Fashion or Fit?", Harward Business Review, January-February, pp. 103-116.

Mintzberg, H. (1983), Structure in Fives: Designing Effective Organizations, Englewood Cliffs, N. J., Prentice Hall.

Nickerson, J. A. and T. R. Zenger, (2002), "Being Efficiently Fickle: A Dynamic Theory of Organizational Choice", Organization Science, 13 (5), pp. 547-566.

Pinsonneault A. and K. L. Kraemer, (2002), "Exploring the Role of Information Technology in Organizational Downsizing", Organization Science, 13 (2), pp. 191-208.

Powell, W. (2001), "The Capitalist Firm in the Twenty-First Century: Emerging Patterns in Western Enterprise" in Di Maggio P. (ed.), The Twenty-First Century Firm, Princeton N.J., Princeton University Press, pp. 33-68.

Rajan, R. and L. Zingales, (2000), "The Governance of the New Enterprise" in Vives, X. (ed.), Corporate Governance, Cambridge, MA., Cambridge University Press, pp. 201-227.

Rajan, R. G. and J. Wulf, (2003), The Flattening Firm: Evidence from Panel Data on the Changing Nature of Corporate Hierarchies, NBER Working Paper No. 9633.

Rathe, K. and U. Witt, (2001), "The Nature of the Firm - Static vs. Developmental Interpretations", Journal of Management and Governance, 5 (3-4), pp. 331-352.

Roberts, J. (2004), The Modern Firm. Organizational Design for Performance and Growth, Oxford, Oxford University Press.

Schilling, M. A. (2000), "Toward a General Modular Systems Theory and Its Application to Interfirm Product Modularity", Academy of Management Review, 25 (2), pp. 312-334.

Simon, H. A. (1951), "A Formal Theory of the Employment Relationship", Ecometrica, 19 (3), pp. 293-305.

Simon, H. A. (1962), "The Architecture of Complexity", Proceedings of the American Philosophical Society, 156, pp. 467-482.

Simon, H. A. (1973), "The Structure of Ill-Structured Problems", Artificial Intelligence, 4, pp. 181-201.

Simon, H. A. (1996), The Sciences of the Artificial, $3^{\text {rd }}$ edition, Cambridge, MA., MIT Press.

Simon, H. A. (2002), "Organization Theory in the Age of Computers and Electronic Communication Networks", in Augier, M. and J. M. 
March (eds.), The Economics of Choice, Change and Organization, Cheltenham, Edward Elgar. pp. 404-418.

Stinchcombe, A. (1985), "Contracts as Hierarchical Documents", in Stinchcombe, A. and C. Heimer (eds.), Organization Theory and Project Management, Oslo, Norwegian University Press, pp. 120171.

Togati, T. D. (2003), Is the New Economy More Stable Than the Old Economy?, Paper for the EAEPE Conference, Maastricht, The Netherlands.

Williamson, O. E. (1991), "Comparative Economic Organization: The Analysis of Discrete Structural Alternatives", Administrative Science Quarterly, 36, pp. 269-296.

Williamson, O. E. (1996), The Mechanisms of Governance, Oxford, Oxford University Press.

Wyatt Data Services (1991) Restructuring - Cure or Cosmetic Surgery: Results of Corporate Change in the '80s with RX's for the '90s, Published Survey Report. Boston, Wyatt.

Zenger, T. and W. S. Hesterley, (1997), "The Disaggregation of Corporations: Selective Intervention, High-Powered Incentives, and Molecular Units", Organization Science, 8, pp. 209-222.

Zenger, T. R. (2002), "Crafting Internal Hybrids: Complementarities, Common Change Initiatives, and the Team-Based Organization", International Journal of the Economics of Business, 9 (1), pp. 7995.

96 Economie et Institutions $-\mathrm{n}^{\circ} 5-2^{\mathrm{e}}$ semestre 2004 